\title{
Antioxidant, Cytotoxic Activities and Total Phenolic Content of Four Indonesian Medicinal Plants
}

\author{
Waras Nurcholis $^{1,2 *}$, Bambang Pontjo Priosoeryanto ${ }^{1,3}$, Edy Djauhari Purwakusumah ${ }^{1,2}$, Takeshi \\ Katayama $^{4}$, Toshisada Suzuki ${ }^{4}$ \\ ${ }^{1)}$ Department of Biochemistry, Faculty of Mathematic and Natural Sciencies, \\ Agricultural University, Agatis Road, Bogor 16680, Indonesia \\ 2) Biopharmaca Research Center, Bogor Agricultural University, No. 03 \\ Taman Kencana Road, Bogor 16128, Indonesia \\ 3) Department of Veterinary Clinic Reproduction and Phatology, \\ Faculty of Veterinary Science, Bogor Agricultural University, Agatis Road, Bogor 16680, Indonesia \\ 4)Department of Applied Biological Science, Faculty of Agriculture, Kagawa University, Kagawa-Japan \\ e-mail: wnurcholis@gmail.com
}

\begin{abstract}
The crude ethanol extracts of four Indonesian medicinal plants namely Curcuma xanthorrhiza Roxb., Phyllanthus niruri Linn., Andrographis paniculata Ness., and Curcuma aeruginosa Roxb. were examined for their antioxidant (radical scavenging) activity using 2, 2-diphenyl-2-picrylhydrazyl (DPPH) free radical and cytotoxicity using brine shrimp lethality test (BSLT). The total phenolic content was used the Folin-Ciocalteu method. $\mathrm{IC}_{50}$ values for DPPH radical scavenging activity ranged from 14.5 to $178.5 \mu \mathrm{g} / \mathrm{ml}$, with $P$. niruri having the lowest value and therefore the most potent, and $C$. aeruginosa having the highest value. $\mathrm{LC}_{50}$ values for BSLT ranged from 210.3 to $593.2 \mu \mathrm{g} / \mathrm{ml}$, with $C$. xanthorrhiza and $A$. paniculata having the lowest and highest values, respectively. The total phenolic content of the Indonesian plants ranged from $133.0 \pm 3.7$ to $863.3 \pm 54.7 \mathrm{mg}$ tannic acid equivalent per $1 \mathrm{~g}$ extract, with $C$. aeruginosa and $P$. niruri having the lowest and highest values, respectively. A positive correlation between free radical scavenging activity and the content of phenolic compounds was found in the four of Indonesian medicinal plants.
\end{abstract}

Keywords : Indonesian medicinal plants; DPPH radical scavenging activity; Brine shrimp lethality test; phenolic content

\section{INTRODUCTION}

Free radicals or other reactive oxygen species are derived either from normal essential metabolic processes in the human body or from external sources such as exposure to radiation, ozone, cigarette smoking, air pollutants and industrial chemicals [1]. The over production of free radicals such as hydroxyl radical, super oxide anion radical, hydrogen peroxide can cause damage to the body and contribute to oxidative stress $[2,3]$. There are various studies emphasizing that free radicals contribute to the development of many diseases, including hemorrhagic shock, arthritis, ageing, atherosclerosis, ischemia, Alzheimer and Parkinson's disease, gastrointestinal disorders, tumor promotion and carcinogenesis [1]. Antioxidants are substances that play an important role in delaying or preventing degenerative diseases caused by oxidative damage of living cell components caused by free radicals [4]. Although the human body produces antioxidant enzymes to neutralize free radicals [5], a diet rich in edible antioxidants is recommended to assist the human body to protect itself from food borne free radicals. There are several reports on the contribution of phenolic compounds to the antioxidant potential of different medicinal plant species. Cai et al. 
[6], for example, reported a positive linear correlation between the total content of phenolic compounds and the antioxidant activities for aqueous and methanolic extracts of Chinese medicinal plants. Similarly, a positive correlation was reported for aqueous and methanolic extracts of different Jordanian plant species [7].

The brine shrimp (Artemia salina) has been utilized in various bioassay systems. The in-vitro toxicity test using brine shrimps lethality assay is a simple, common, inexpensive, and rapid method to predict the antitumor and pesticidal activities [8]. It has also been used to evaluate the cytotoxicicity and pesticidal activity [9].

Indonesia is rich of medicinal plants, where records of the Indonesia Institute of Sciences have shown that there are about 30.000 out of 40.000 medicinal plants in the world. Medicinal plants play a crucial role in health care needs of people around the world especially in developing countries [10, 11], like the Indonesia. In the Indonesia, medicinal plants are considered to be one of its natural living treasures. They is play a key role in the development and advancement of modern studies by serving as a starting point for the development of novelties in drugs [12]. Approximately $25 \%$ of drugs used in modern Pharmacopoiea are derived from plants and many others are synthetic analogues built on prototype compounds isolated from plants [13]. Medicinal plant use however, has been based mostly on empirical grounds. There is a need for scientific validation of such empirical knowledge. The medicinal plants before used for human should has been scientifically validated for safety, efficacy, and quality. Thus, four Indonesian medicinal plants were selected to evaluate their bio-activities in different assay include rhizomes of Curcuma xanthorrhiza Roxb. and Curcuma aureginosa Roxb. and leaves of Phyllanthus niruri Linn. and Andrographis paniculata Ness.

C. xanthorrhiza Roxb., also know as "temulawak" in Indonesia, is a medicinal plant from the family Zingeberaceae distributed in Indonesia. Traditionally, its rhizomes have been used to treat stomach diseases, liver disorders, constipation, bloody diarrhea, dysentery, children's fevers, hemorrhoids, and skin eruptions [14]. Pharmacologically is has been reported that Curcuma has antimicrobial [14], anti-metastatic [15], anti-cancer [16], anticandidal [17], anti-oxidant [18], and hypolipidemic activities [19]. C. aeruginosa Roxb. (Zingiberaceae) is known in Indonesia as "temu ireng". The rhizome of this plant is used medicinally to treat asthma and cough, scurvy and mental derangements [20]. Relatively few pharmacological studies have been conducted on C. aeruginosa Roxb., which have indicated antiinflammatory properties [21], inhibitory of HIVI [22], and anti cancer activity [23]. P. niruri Linn. is an annual and field weed widespread in temperate and tropical climates [24]. P. niruri Linn. from the Euphorbiaceae family is known as "meniran" in Indonesia. It's leaves have been used in Asia, Africa and South America [25] as a stomachic, aperitive, antispasmodic, antihepatotoxic, antiviral, antibacterial, laxative, diuretic, carminative, in the management of diabetes, constipation, fever including malaria, jaundice, hepatitis B, dysentery, gonorrhea, syphilis, tuberculosis, cough, influenza, diarrhea, vaginitis, tumors, kidney stones[26-31]. $P$. niruri Linn. has been proved scientifically to have antioxidant [32], antimalarial [33, 34], antihyperuricemic [35], hypoglycemic [36], hepatoprotective [37, 38], hypolipemic [39], and HIV replication inhibitory [40] activities. A. paniculata Ness. (Achanthaceae) is a medicinal plant, commonly known as named locally 'sambiloto' in Indonesia. Pharmacological research has demonstrated that $A$. paniculata possesses antimicrobial activity [41], antiviral properties [42], hepatoprotective and antioxidant [43], antidiabetic [44], antihyperglycaemic [45] and antiangiogenic activity [46], in addition to anti inflammatory properties [47], and it is used in the treatment of upper respiratory tract infections [48]. This study was undertaken to assess different Indonesian plants for their antioxidant activity, cytotoxicity and total phenolic content of some ethanolic extract, and to determine the relationships between antioxidant activity, cytotoxicity, and phenolic contents. 


\section{MATERIALS AND METHODS}

\section{Materials}

The rhizomes of $C$. xanthorrhiza and $C$. aeruginosa and the leaves of $P$. niruri and $A$. Paniculata were collected from The Conservation and Cultivation Unit of Biopharmaca Research Center, Bogor Agricultural University, in April 2011. Voucher specimens of material plants were deposited in the herbarium of the Indonesia Institute of Sciences, Indonesia. The 2, 2-Diphenyl-2picrylhydrazyl, Folin-Ciocalteu's phenol reagent, tannic acid, and anhydrous sodium carbonate were obtained from Sigma-Aldrich, USA. The ethanol and DMSO were purchased from E Merck, Germany. While, Artemia salina eggs was obtained from aquarium shops Bogor, Indonesia. All the chemicals and solvents used were analytical grade.

\section{Extraction of plants}

Fresh rhizomes and leaves of plant materials were washed with water, cut into small pieces and dried for 5 days in the sun (the moisture: $<10 \%)$. They were then ground in a grinder to be obtained in a powder form (the size: 80 mesh). One kilo grams of the powder of plants were macerated using $1 \times 10 \mathrm{~L}$ ethanol $70 \%$ in a tightly closed round bottom flask at room temperature for a period of $24 \mathrm{~h}$ and filtered with Whatman filter paper (type 4). The whole process was repeated one times and the filtrate was concentrated under reduced pressure on rotavapor (BUCHI, R-250, Switzerland) at 50 ${ }^{\circ} \mathrm{C}$ temperature. The concentrated extracts were then used for the experiments.

\section{Measurement of free radical scavenging capacity by DPPH assay}

The method of [49] with a modification was used for evaluating the DPPH (2, 2Diphenyl-2-picrylhydrazyl) radical scavenging ability of the extracts. The different concentrations of the plant extracts (12.5-200 $\mu \mathrm{g} / \mathrm{ml}$; total volume of $40 \mu \mathrm{L}$ ) in 96-well plates were mixed with $160 \mu \mathrm{L}$ of $100 \mathrm{mM}$ DPPH in ethanol and then incubated in the dark for 30 min at room temperature prior to reading the absorbance at $517 \mathrm{~nm}$ in a micro plate reader. A negative control, containing water instead of the sample and blank samples, using the same volume of ethanol only in place of the DPPH solution in ethanol, were all evaluated at the same time per micro titre plate.

The percentage of radical scavenging was calculated as follows;

$\%$ radical scavenging $=\frac{(A c-A c b)-(A s-A s b)}{(A c-A c b)} \times 100$

where Ac is the absorbance of water plus DPPH (in ethanol), Acb is the absorbance of the blank (water plus ethanol without DPPH), As is the absorbance of the sample plus DPPH (in ethanol) and Asb is the absorbance of the sample plus ethanol without DPPH. Different sample concentrations were used in order to obtain calibration curves and to calculate the $\mathrm{IC}_{50}$ values $\left(\mathrm{IC}_{50}\right.$ : concentration required to obtain a 50\% radical scavenging activity). All test samples were conducted in triplicate $(n=3)$.

\section{Brine shrimp lethality test (BSLT)}

The assay was carried out according to the principle and protocol previously described by [50, 51, 52], with slight modifications. Brine shrimp eggs (Artemia salina) were placed on one side of a small tank which was filled with boiled, filtered sea water, covered with aluminum foil, and fully aerated. After $48 \mathrm{~h}$ incubation at room temperature and under illumination, the resulting nauplii (larvae) were attracted to the other side of the tank with a light source and collected with a Pasteur pipette. Ten shrimps were transferred to each sample vial and artificial sea water was added (where the extract was made in organic solvent) to make a concentration of $10,50,100$, $500,1000 \mathrm{mg} / \mathrm{mL}$ (in the case of ethanolic extract a dilution of $2000 \mathrm{mg} / \mathrm{ml}$ was also prepared). Survivors were counted under the stereomicroscope after $24 \mathrm{~h}$ and the percent death at each dose and control was determined. The lethal concentrations of plant extracts resulting in 50\% mortality of the brine shrimp $\left(\mathrm{LC}_{50}\right)$ was determined from the $24 \mathrm{~h}$ counts and the dose-response data were transformed into a straight line by means of a trendline fit linear 
regression analysis (MS Excel version 7); the LC50 was derived from the best-fit line obtained.

\section{Determination of total phenolic content}

The total phenolic content (TPC) assay was determined in accordance [53] with modification. In brief, $2 \mathrm{~mL}$ of test samples were mixed with $5 \mathrm{ml}$ of water destilated and $0.5 \mathrm{ml}$ of $50 \%$ Folin-Ciocalteu phenol reagent in a test tube and kept for $5 \mathrm{~min}$. After that, $1 \mathrm{ml}$ of $5 \%$ sodium carbonate solution was then added. Reactions were kept in a dark place for $1 \mathrm{~h}$, and then read for UV absorbance at $725 \mathrm{~nm}$. Tannic acid solution (ranging from $0 \mu \mathrm{g} / \mathrm{ml}$ to $90 \mu \mathrm{g} / \mathrm{ml}$ ) was used as a standard curve. TPC of each sample was expressed as $\mathrm{mg}$ tannic acid equivalent (TAE) per $1 \mathrm{~g}$ extract.

\section{Statistical Analysis}

The data were analyzed by Statistical Package Social Science (SPSS) version 17.0. One-way ANOVA were used to show the mean differences between all samples.

\section{RESULTS AND DISCUSSION}

\section{DPPH radical scavenging activity}

Fig. 1 shows the DPPH radical scavenging activity of the different successive extracts of four Indonesian plants. This activity was increased by increasing the concentration of sample extracts. DPPH antioxidant assay is based on the ability of 2, 2- Diphenyl-1picrylhydrazyl (DPPH), a stable free radical, to decolorize in the presence of antioxidants. The DPPH radical contains an odd electron, which is responsible for the absorbance at $517 \mathrm{~nm}$ and also for a visible deep purple color. When DPPH accepts an electron donated by an antioxidant compound, the DPPH is decolorized, which can be quantitatively measured from the changes in absorbance. Thus, the DPPH radicals were widely used to investigate the scavenging activity of some natural compounds. DPPH is widely used to evaluate the antioxidant activity of natural compounds [49]. However, DPPH's scavenging activity indicates the ability of the antioxidant compound to donate electrons or hydrogen, thereby converting the radical to a more stable species [54]. The result of DPPH free radical scavenging activity on the four crude ethanol extracts are shown in Table 1. The highest radical scavenging activity $\left(\mathrm{IC}_{50}\right.$ value, $14.5 \mu \mathrm{g} / \mathrm{ml}$ ) was shown by $P$. niruri; this was followed by A. paniculata and C. xanthorrhiza, with $\mathrm{IC}_{50}$ values of 30.5 and $85.7 \mu \mathrm{g} / \mathrm{ml}$, respectively. The lowest radical scavenging activity was shown by $C$. aeruginosa $\left(\mathrm{IC}_{50}\right.$ value of $178.5 \mu \mathrm{g} / \mathrm{ml}$ ).

Of the four Indonesian medicinal plants examined, $P$. niruri leaves appears to be the most promosing source of antioxidant compounds. Harish and Shivanandappa [56] reported the $\mathrm{DPPH}$ scavenging efect $\left(\mathrm{IC}_{50} 15.3\right.$ $\mu \mathrm{g} / \mathrm{ml}$ and $9.1 \mu \mathrm{g} / \mathrm{ml}$ ) and total phenolic content (97.4 mg of GEA/g and $105 \mathrm{mg}$ of GEA /g ) of the aqueous and methanolic extracts of $P$. niruri leaves. Compared to our results (Table 1 and Fig. 2), ethanolic extract of $P$. niruri leaves had a higher content of total phenolic compounds $(863.3 \pm 54.7 \mathrm{mg}$ of $\mathrm{TAE} / \mathrm{g}$ ) than aqueous and methanolic extracts. On the other hand, the ethanolic extracts of $P$. niruri leaves had a higher and lower stable DPPH free radical scavenging activity $\left(\mathrm{IC}_{50} 14.5 \mu \mathrm{g} / \mathrm{ml}\right)$ than the aqueous and methanolic extracts.

\section{Brine shrimp lethality test}

The brine shrimp lethality test (BSLT) has been used routinely in the primary screening of the crude extracts as well as isolated compounds to assess the toxicity towards brine shrimp, which could also provide an indication of possible cytotoxic properties of the test materials. Brine shrimp nauplii have been previously utilized in various bioassay systems. Among these applications have been the analyses of pesticidal residues, mycotoxins, stream pollutants, anesthetics, dinoflagelate toxins, morphine-like compounds, carcinogenicity of phorbol esters and toxicants in marine environment. A number of novel antitumor and pesticidal natural products have been isolated using this bioassay $[8,55]$. The results of BSLT on crude ethanol extracts of the 


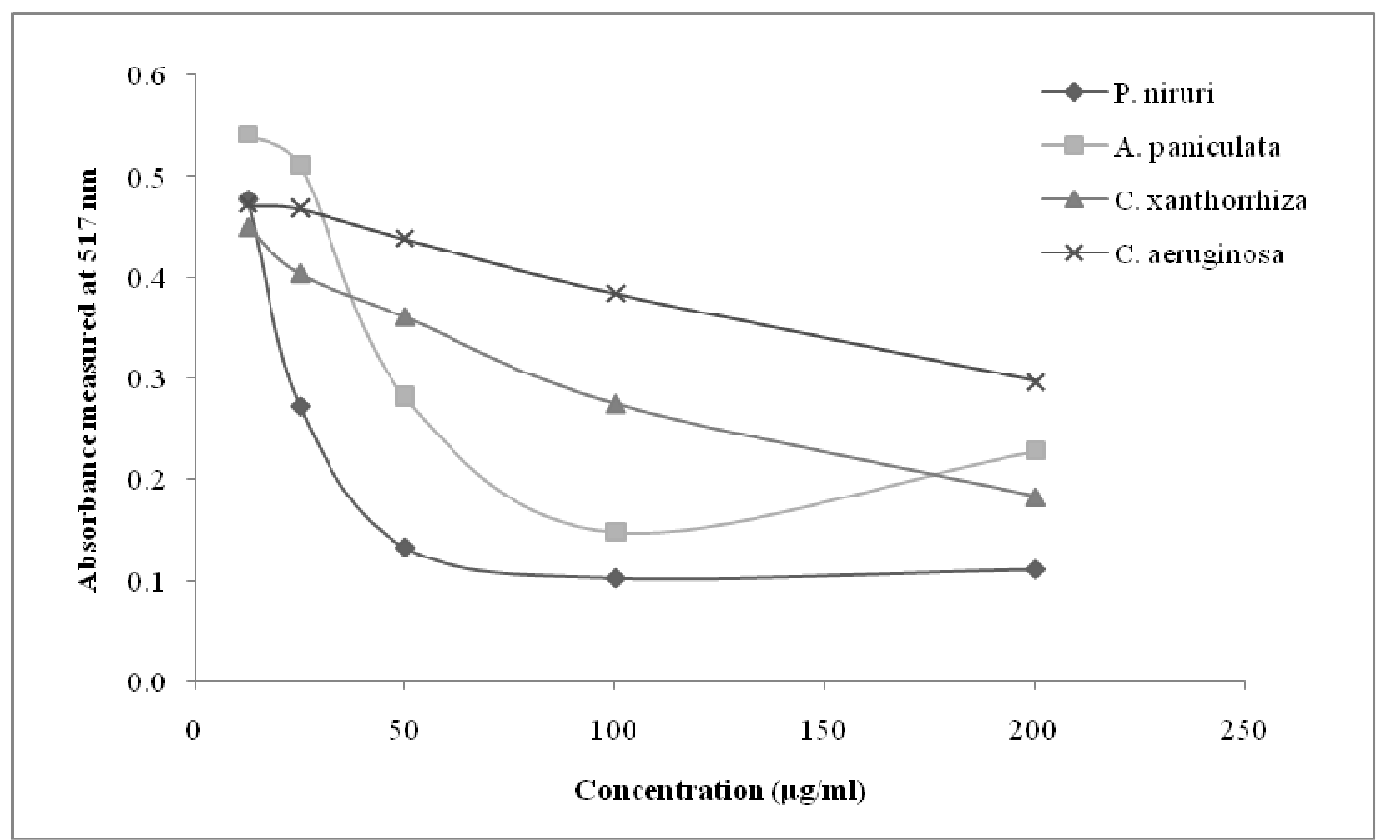

Fig. 1. Scavenging effect of four Indonesian plants on 2,2-diphenyl-1-picrylhydrazyl (DPPH), as measured by changes in absorbance at $517 \mathrm{~nm}$.

Table 1. DPPH free radical scavenging activity of crude ethanol extracts of four Indonesian medical plants.

\begin{tabular}{|c|c|c|c|c|c|c|}
\hline \multirow[t]{2}{*}{ Plant } & \multicolumn{5}{|c|}{$\%$ Inhibition at different concentration* } & \multirow{2}{*}{$\frac{\mathrm{IC}_{50}}{\mu \mathrm{g} / \mathrm{ml}}$} \\
\hline & $12.5 \mu \mathrm{g} / \mathrm{ml}$ & $25 \mu \mathrm{g} / \mathrm{ml}$ & $50 \mu \mathrm{g} / \mathrm{ml}$ & $100 \mu \mathrm{g} / \mathrm{ml}$ & $200 \mu \mathrm{g} / \mathrm{ml}$ & \\
\hline C. xanthorrhiza & $6.3 \pm 1.4$ & $17.8 \pm 1.4$ & $29.8 \pm 1.9$ & $50.2 \pm 3.6$ & $77.8 \pm 2.2$ & 85.7 \\
\hline C. aureginosa & $5.7 \pm 2.2$ & $8.0 \pm 2.5$ & $16.0 \pm 4.3$ & $31.9 \pm 4.0$ & $62.3 \pm 2.3$ & 178.5 \\
\hline$P$. niruri & $37.5 \pm 13.0$ & $66.2 \pm 14.3$ & $87.8 \pm 4.4$ & $94.2 \pm 0.3$ & $98.9 \pm 1.7$ & 14.5 \\
\hline A. paniculata & $27.5 \pm 10.6$ & $34.5 \pm 4.8$ & $70.0 \pm 3.7$ & $90.4 \pm 6.0$ & $97.4 \pm 8.9$ & 30.5 \\
\hline
\end{tabular}

*Data are expressed as the mean of triplicate \pm SD.

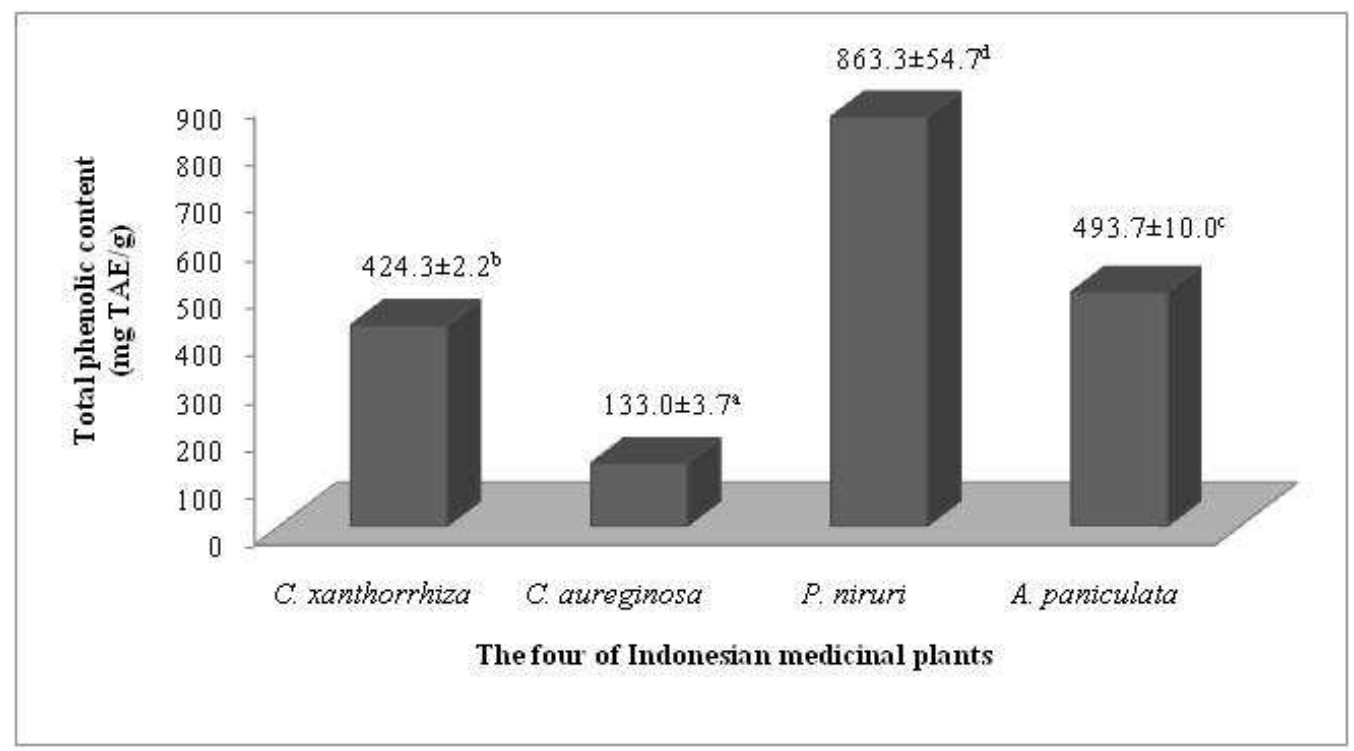

Fig. 2. Total phenolic content in extracts of four Indonesian medicinal plants. The expressed values are means \pm SD of three replicates; those with different letters differ significantly at $\mathrm{p}<0.05$. 
Table 2. Results of Brine Shrimp Lethality Test on crude ethanol extracts from four Indonesian medicinal plants.

\begin{tabular}{llllll}
\hline Plant & \% Mortality at different concentrations* & $\mathbf{L C}_{\mathbf{5 0}}, \mathbf{2 4} \mathbf{~ h}$ \\
\hline & $\mathbf{1 0} \boldsymbol{\mu} \mathbf{g} / \mathbf{m l}$ & $\mathbf{1 0 0} \mathbf{\mu g} / \mathbf{m l}$ & $\mathbf{5 0 0} \boldsymbol{\mu g} / \mathbf{m l}$ & $\mathbf{1 0 0 0} \boldsymbol{\mu g} / \mathbf{m l}$ & $\mathbf{\mu g} / \mathbf{m l}$ \\
\hline C. xanthorrhiza & 10.0 & 56.7 & 93.3 & 100.0 & 210.3 \\
C. aureginosa & 26.7 & 33.3 & 93.3 & 100.0 & 233.6 \\
P. niruri & 16.7 & 33.3 & 50.0 & 76.7 & 507.7 \\
A. paniculata & 16.7 & 36.7 & 46.7 & 66.7 & 593.2 \\
\hline
\end{tabular}

*mean of 3 determinations.

four Indonesian medicinal plants (\% mortality at different concentrations and LC50 values) are shown in Table 2. The percentage mortality increased with an increase in concentration. $\mathrm{LC}_{50}$ values ranged from 210.3 to $593.2 \mu \mathrm{g} / \mathrm{mL}$, with C.xanthorrhiza rhizomes having the lowest value (most potent); this was followed by C.aeruginosa rhizomes $(233.6 \mu \mathrm{g} / \mathrm{mL})$, then by P.niruri leaves $(507.7 \mu \mathrm{g} / \mathrm{ml})$ and lastly A.paniculata leaves $(593.2 \mu \mathrm{g} / \mathrm{ml})$. The variation in BSLT results may be due to the difference in the amount and kind of cytotoxic substances present in the crude ethanol extracts. Moreover, this significant lethality of the crude plant extracts $\left(\mathrm{LC}_{50}\right.$ values was $1000 \mu \mathrm{g} / \mathrm{mL}$ or less [8]) to brine shrimp is indicative of the presence of potent cytotoxic and bioactive compounds which warrants further investigation. BSLT results may be used to guide the researchers on which crude plant extracts/fractions to prioritize for further fractionation and isolation of these bioactive compounds. Other cytotoxicity tests and specific bioassays may be done on the isolated bioactive compounds later.

\section{Total phenolic content (TPC)}

There was a wide range of phenolic concentrations in the plant extracts analyzed as shown in Fig. 2. The values varied from $133.0 \pm 3.7$ to $863.3 \pm 54.7 \mathrm{mg}$ TAE/g of sample as mesured by the Folin-Ciocalteau method, which represents a variation of approximately 6 fold. The four of Indonesian medicinal plants showed a very high phenolic content: $P$. niruri (863.3 $\pm 54.7 \mathrm{mg} \mathrm{TAE} / \mathrm{g}), \quad$ A. paniculata (493.7 $\pm 10.0 \mathrm{mg} \mathrm{TAE} / \mathrm{g}), \quad C$. xanthorrhiza $(424.3 \pm 2.2 \mathrm{mg} \mathrm{TAE} / \mathrm{g})$, and $C$. aeruginosa (133.0 $\pm 3.7 \mathrm{mg}$ TAE/g). Overall, the highest and the lowest phenolic content were found in $P$. niruri and $C$. aeruginosa, respectively. Similiar observation was found for their antioxidant activity. Polyphenols are the major plant compounds with antioxidant activity [57]. Typical phenolics that possess antioxidant activity are known to be mainly phenolic acids and flavonoids [58]. The phyllanthin, hypophyllanthin and flavonoids, like niruriflavone, gallic acid and ellagic acid were phenolic compounds present in the P.niruri [59]. The curcuminoids [18] and phenolic diarylheptanoids [60] were phenolic compounds present in $C$. xanthorrhiza. In the A. paniculata and $C$. aeruginosa had phenolic compounds due to antioxidant activity $[61,62]$. The variation in the antioxidant activity of the plant responsible was phenolic content [63]. They exhibit antioxidant activity by inactivating lipid free radicals or preventing decomposition of hydro peroxides into free radicals $[64,65]$. Flavonoids are phenolic acids which serve as an important source of anti-oxidants found in different medicinal plants and related phytomedicies [66]. The anti-oxidant activity of flavonoids is due to their ability to reduce free radical formation and to scavenge free radicals.

\section{Correlation betweenTPC, DPPH, and BSLT}

Person's correlation analysis was performed to investigate the relationship between TPC, DPPH, and BSLT of the four Indonesian medicinal plant extracts. A significant, positive, and negative correlation was found between the TPC level, DPPH and BSLT activities for the four Indonesian medicinal plant extracts (Table 3). A positive corellation was found between TPC and DPPH assay $(r=0.877)$. The negative correlation was found between DPPH and BSLT followed by DPPH and BSLT were negatively correlation ( $\mathrm{r}$ $=-0.895$ and $\mathrm{r}=-0.624$, respectively). The result indicates that, the TPC and DPPH of the extracts were positively correlated. The finding also was in line with several studies conducted [67, 68, 69]. Based on the result, it can be said that 
polyphenol of the four Indonesian medicinal plants is a potent radical scavenger. The roles of phenolic compounds as the main contributors to the antioxidant activity of various medicinal plants have been reported from previous studies $[67,68,69,70]$.

Table 3. Pearson's correlation coefficients of total phenolic content, DPPH radical scavenging and cytotoxic activities.

\begin{tabular}{lll}
\hline Trait $^{\mathbf{a}}$ & TPC & DPPH \\
\hline DPPH & $0.877^{*}$ & \\
BSLT & $-0.624^{*}$ & $-0.895^{*}$
\end{tabular}

${ }^{\mathrm{a}} \mathrm{TPH}=$ total phenolic content, DPPH $=1,1$-diphenyl-2-picrylhydrazyl, BSLT $=$ brine shrimpt lethality test. $*=$ significant at $\mathrm{P}<0.05$.

\section{CONCLUSIONS}

The study indicates the presence of antioxidants, cytotoxic, and phenolic compound in crude ethanol extracts of four Indonesian medicinal plants namely C.xanthorrhiza Roxb., P.niruri Linn., A.paniculata Ness., and C.aeruginosa Roxb. The highest radical scavenging activity ( $\mathrm{IC}_{50}$ value, $14.5 \mu \mathrm{g} / \mathrm{ml}$ ) was shown by $P$. niruri; this was followed by $A$. paniculata, C. xanthorrhiza, and $C$. aeruginosa with $\mathrm{IC}_{50}$ values of $30.5,85.7$ and $178.5 \mu \mathrm{g} / \mathrm{ml}$, respectively. The cytotoxicity as $\mathrm{LC}_{50}$ values ranged from 210.3 to $593.2 \mu \mathrm{g} / \mathrm{mL}$, with C.xanthorrhiza rhizomes having the lowest value (most potent); this was followed by C.aeruginosa rhizomes $(233.6 \mu \mathrm{g} / \mathrm{mL})$, then by P.niruri leaves $(507.7 \mu \mathrm{g} / \mathrm{ml})$ and lastly A.paniculata leaves $(593.2 \mu \mathrm{g} / \mathrm{ml})$. The highest phenolic content was shown by $P$. niruri (863.3 $\pm 54.7 \mathrm{mg}$ TAE/g), this was followed by $A$. paniculata $(493.7 \pm 10.0 \mathrm{mg} \quad \mathrm{TAE} / \mathrm{g}), \quad C$. xanthorrhiza $(424.3 \pm 2.2 \mathrm{mg} \mathrm{TAE} / \mathrm{g})$, and $C$. aeruginosa (133.0 $\pm 3.7 \mathrm{mg}$ TAE/g). A positive corellation was found between TPC and DPPH assay $(r=0.877)$.

\section{ACKNOWLEDGEMENTS}

We express our gratitude to Prof. Dr. Ir. Latifah K Darusman, MS for excellence technical support. This research was supported by grants from the Higher Education Directorate, Ministry of Education Republic of Indonesia (Hibah Kompetitif Penelitian Strategis Nasioanal Nomor: 430/SP2H/PL/Dit.Litabmas/IV/2011).

\section{REFERENCES}

1. Bagchi D; Bagchi M; Stohs S; et al. Free radicals and grape seed proanthocyanidin extract: importance in human health and disease prevention. Toxicology. 2000, 148: 187-197.

2. Diplock AT. Free radical damage and control. In: Rice Evans CA and Burden RH, ed. Antioxidant and free radical scavengers. Elsevier, New York, USA. 1994.

3. Thomson MJ. The role of free radicals and antioxidants; How do we know that they are working? Critical Reviews of Food Science and Nutrition. 1995, 35:21-29.

4. Jaitak V; Sharma K; Kalia K; et al. Antioxidant activity of Potentilla fulgens: An alpine plant of western Himalaya. J. Food Compost. Anal. 2010, 23: $142-147$

5. Rimbach G, Fuchs J, Packer L. Application of nutrigenomics tools to analyze the role of oxidants and antioxidants in gene expression. In: Rimbach G, Fuchs J, Packer L (eds.), Nutrigenomics, Taylor and Francis Boca Raton Publishers, FL, USA. 2005, pp. 1-12

6. Cai Y, Luo Q, Sun M, Corke H. Antioxidant activity and phenolic compounds of 112 traditional Chinese medicinal plants associated with anticancer. Life Sci. 2004, 74: 2157-2184

7. Tawaha K, Alali FQ, Gharaibeh M, et al. Antioxidant activity and total phenolic content of selected Jordanian plant species. Food Chem. 2007, 104: 1372-1378

8. Meyer BN, Ferrigni NR, Putnam JE, et al. Brine Shrimp: A convenient general bioassay for active plant constituents. Planta Med. 1982, 45: 31-34. 
9. Ghisalberti EL. Detection and isolation of bioactive natural products. In: Colgate SM and Molyneux RJ (eds.) Bioactive natural products: detection, isolation and structural determination. CRC Press, USA. 1993.

10. Bekalo TH, Woodmatas SD, Woldemariam ZA. An ethnobotanical study of medicinal plants used by local people in the lowlands of Konta Special Woreda, Southern nations, nationalities and peoples regional state, Ethiopia. J. Ethnobio. Ethnomed. 2009, 5:26

11. Rao MR, Palada MC, Becker BN. Medicinal and aromatic plants in agro forestry systems. Agroforestry System, 2004, (61) : 107-122

12. Oladele AT, Alade GO, Omobuwajo OR. Medicinal plants conservation and cultivation by traditional medicine practitioners (TMPs) in Aiyedaade Local Government Area of Osun State, Nigeria. Agric. Biol. J. N. Am. 2011, 2(3): 476-487

13. Pramono E. The Commercial use of traditional knowledge and medicinal plants in Indonesia. Multi-stakeholder dialogue on trade, intellectual property and biological resources in Asia, BRAC Rajendrapur, Bangladesh, 2002, 1-13

14. Hwang J, Shim, J, Pyun, Y. Antibacterial activity of xanthorrhizol from Curcuma xanthorrhiza against oral pathogens. Fitoterapia. 2000, 71: 321-323.

15. Choi M, Kim S, Chung W, et al. Xanthorrhizol, a natural sesquiterpenoid from Curcuma xanthorrhiza, has an anti-metastatic potential in experimental mouse lung metastasis model. Biochem. Biophys. Res. Commun. 2004, 326: 210-217.

16. Huang M, Lou Y, Xie J, et al. Effect of dietary curcumin and dibenzoylmethane on formation of 7, 12-dimethylbenz [a] anthracene-induced mammary tumors and lymphomas/leukemias in Sencar mice. Carcinogenesis. 1998, 19: $1697-$ 1700.

17. Rukayadi Y, Yong D, Hwang JK. In vitro anticandidal activity of xanthorrhizol isolated from Curcuma xanthorrhiza Roxb. J Antimicrob. Chemother. 2006, 132: 1-4.

18. Masuda T, Isobe J, Jitoe A, et al. Antioxidative curcuminoids from rhizomes of Curcuma xanthorrhiza. Phytochemistry. 1992, 31: 36453647

19. Yasni S, Imaizumi KT, Nakamura M, et al. Effects of Curcuma xanthorrhiza Roxb. And curcuminoids on the level of serum and liver lipids, serum apolipoprotein A-I and lipogenic enzymes in rats. Food.Chem.Toxic. 1993, 31: 213-218

20. Perry LM. Medicinal plant of East and Southeast Asia: attributed properties and uses, The MIT Press, Massachusetts, USA. 1980, p. 439

21. Reanmongkol W, Subhadhirasakul S, Khaisombat $\mathrm{N}$, et al. Investigation the antinociceptive, antipyretic and antiinflammatory activities of Curcuma aeruginosa Roxb. extracts in experimental animals. Songklanakarin J. Sci. Technol. 2006, 28(5) : 999-1008.

22. Otake T, Mori H, Morimoto M, et al. Screening of Indonesian plant extracts for antihuman immunodeficiency virus-type 1 (HIV-1) activity. Phytother. Res. 1995, 9: 6-10.

23. Jantan I, Rafi IAA, Jalil J. Plateletactivating factor (PAF) receptor-binding antagonist activity of Malaysian medicinal plants. Phytomedicine. 2005, 12: 88-92.

24. Iizuka T, Moriyama H, Nagai M. Vasorelaxant effects of methyl brevifolincarboxylate from the leaves of Phyllanthus niruri. Biol. Pharm. Bull. 2006, 29: 177-179

25. Mellinger CG, Carbonero ER, Noleto GR, et al. Chemical and biological properties of an arabinogalactan from Phyllanthus niruri. J. Nat. Prod.2005, 68: 1479-83.

26. Syamasundar KV. Antihepatoprotective principles of Phyllanthus niruri herbs. J. Ethnopharmacol. 1985, 14: 41-44.

27. Olive-Bever B. Medicinal plants in tropical West Africa. Cambridge University Press, Cambridge, ISBN: 052126815X. 1986, pp: 375.

28. Chopra RN, Nayar SL, Chopra IC. Glosssary of indian medicinal plants. CSIR., Catholic Press, New Delhi, Ranchi, India. ISBN: 8172361262, 1986.

29. Unander DW, Webster GL, Blumberg BS. Usage and bioassays in Phyllanthus (Euphorbiaceae). IV. Clustering of antiviral uses and other effects. J. Ethnopharmacol. 1995, 45: 1-18.

30. Paranjape P. Indian Medicinal Plants: Forgotten Healers. Chaukhamba Sanskrit Pratisthan, Delhi, 2001 pp: 315.

31. Lin TJ, Su CC, Lan CK, et al. Acute poisonings with Breynia officinalis-an outbreak of hepatotoxicity. J. Toxicol. Clin. Toxicol. 2003, 41: 591-594. 
32. Tasaduq SA, Singh $\mathrm{K}$, Sethi $\mathrm{S}$, et al. Hepatocurative and antioxidant profile of HP-1, a polyherbal phytomedicine. Hum. Exp. Toxicol. 2003, 22: 639-645.

33. Tona L, Ngimbi NP, Tsakala M, et al. Antimalarial activity of 20 crude extracts from nine African medicinal plants used in Kinshasa, Congo. J. Ethnopharmacol. 1999, 68: 193-203.

34. Tona L, Mesia K, Ngimbi NP, et al. In vivo antimalarial activity of Cassia occidentalis, Morinda morindoides and Phyllanthus niruri. Ann. Trop. Med. Parasitol. 2001, 95: 47-57.

35. Murugaiyah V, Chan KL. Antihyperuricemic lignans from the leaves of Phyllanthus niruri. Planta Med. 2006, 72: 1262-7.

36. Ramakrishnan PN, Murugesan R, Palanichamy S. Oral hypoglycaemic effect of Phyllanthus niruri leaves. Indian J. Pharm. Sci. 1982, 44: 1012.

37. Chatterjee M, Sil PC. Hepatoprotective effect of aqueous extract of Phyllanthus niruri on nimesulide-induced oxidative stress in vivo. Indian J. Biochem. Biophys. 2006, 43: 299-305.

38. Sarkar MK, Sil PC. Hepatocytes are protected by herb Phyllanthus niruri protein isolate against thioacetamide toxicity. Pathophysiology. 2007, 14: 113-120.

39. Khanna AK, Rizvi F, Chander R. Lipid lowering activity of Phyllanthus niruri in hyperlipemic rats. J. Ethnopharmacol. 2002, 82: 19-22.

40. Bhattacharjee R, Sil PC. The Protein fraction of Phyllanthus niruri plays a protective role against acetaminophen induced hepatic disorder via its antioxidant properties. Phytother. Res. 2006, 20: 595-601.

41. Singha P, Roy S, Dey S. Antimicrobial activity of Andrographis paniculata. Fitoterapia. 2003, 74: 692-694.

42. Wiart C, Kumar K, Yusof M, et al. Antiviral properties of ent-labdene diterpenes of Andrographis paniculata Nees., inhibitors of herpes simplex virus type 1 . Phytother. Res. 2005, 19: 1069-1070.

43. Trivedi N, Rawal U. Hepatoprotective and antioxidant property of Andrographis paniculata (Nees) in BHC induced liver damage in mice. Indian J. Exp. Biol. 2001, 39: 41.

44. Reyes B, Bautista N, Tanquilut N, et al. Antidiabetic potentials of Momordica charantia and Andrographis paniculata and their effects on estrous cyclicity of alloxan-induced diabetic rats. J. Ethnopharmacol. 2006, 105: 196-200.

45. Husen R, Pihie A, Nallappan M. Screening for antihyperglycaemic activity in several local herbs of Malaysia. J. Ethnopharmacol. 2004, 95: 205 208 .

46. Sheeja K, Guruvayoorappan C, Kuttan G. Antiangiogenic activity of Andrographis paniculata extract and andrographolide. Int. Immunopharmacol. 2007, 7: 211-221.

47. Liu J, Wang Z, Ji L. In vivo and in vitro antiinflammatory activities of neoandrographolide. Am. J. Chin. Med. 2007, 35: 317-328.

48. Coon J, Ernst E. Andrographis paniculata in the treatment of upper respiratory tract infections: a systematic review of safety and efficacy. Planta Med. 2004, 70: 293-298.

49. Udenigwe CC, Lu YL, Han CH, et al. Flaxseed protein-derived peptide fractions: Antioxidant properties and inhibition of lipopolysaccharideinduced nitric oxide production in murine macrophages. Food. Chem. 2009, 116(1): 277284.

50. Krishnaraju AV, Rao TVN, Sundararaju D, et al. Assessment of bioactivity of Indian medicinal plants using brine shrimp (Artemia salina) lethality assay. Int. J. Appl. Sci. Eng. 2005, 3(2): $125-134$

51. Meyer BN, Ferrigni NR, Putnam JE, et al. Brine Shrimp: A convenient general bioassay for active plant constituents. Planta Med. 1982, 45: 31-34.

52. Ara J, Sultana V, Ehteshamul-Haque S, et al. Cytotoxic activity of marine macro-algae on Artemia salina (brine shrimp). Phytother. Res. 1999, 13: 304-307.

53. Stoilova I, Krastanov A, Stoyanova A, et al. Antioxidant activity of a ginger extract (Zingiber officinale). Food Chem. 2007, 102: 764-770.

54. Bougatef A, Hajji M, Balti R, et al. Antioxidant and free radical-scavenging activities of smooth hound (Mustelus) muscle protein hydrolysates obtained by gastrointestinal proteases. Food Chem. 2009, 114: 1198-1205.

55. Sam TW. 1993. Toxicity testing using the brine shrimp: Artemia salina. In: Colegate SM and Molyneux RJ (Eds.), Bioactive Natural Products Detection, Isolation, and Structural Determination. CRC Press, Boca Raton. 1993, FL: 442-456. 
56. Harish R, Shivanandappa T. Antioxidant activity and hepatoprotective potential of Phyllanthus niruri. Food Chem. 2006, 95: 180-185.

57. Premanath R, Lakshmidevi N. Studies on antioxidant activity of Tinospora cordifolia (Miers.) leaves using in vitro models. J. Am. Sci. 2010, 6(10): 736-743.

58. Demiray S, Pintado ME, Castro PML. Evaluation of phenolic profiles and antioxidant activities of Turkish medicinal plants: Tilia argentea, Crataegi folium leaves and Polygonum bistorta roots. World Academy of Science, Engineering and Technology, 2009, 54:312-317.

59. Thippeswamy AHM, Shirodkar A, Koti BC, et al. Protective role of Phyllantus niruri extract in doxorubicin-induced myocardial toxicity in rats. Indian J Pharmaco. 2011, 43: 31-35.

60. Suksamrarn A, Elamong S, Plyachaturawat $\mathrm{P}$, et al. Phenolic diarylheptanoids from Curcuma xanthorrhiza. Phytochemistry. 1994, 36: 15051508.

61. Rafat A, Philip K, Muniandy S. Antioxidant potential and content of phenolic compounds in ethanolic extracts of selected parts of Andrographis paniculata. J. Med. Plant. Res. 2010, 4(3): 197-202.

62. Jitoe A, Masuda T, Tengah IGP, et al. Antioxidant activity of tropical ginger extracts and analysis of the contained of curcuminoids. J. Agric. Food Chem. 1992, 40(8): 1337-1340.

63. Luo Q, Cai Y, Sun M, et al. Antioxidant activity and phenolic compounds of 112 traditional Chinese medicinal plants associated with anticancer. Life Sci. 2004, 74:2157-2184.

64. Pitchaon M, Suttajit M, Pongsawatmani R. Assessment of phenolic content and free radical scavenging capacity of some Thai indigenous plants. Food Chem. 2007, 4:1409-1418.

65. Pokorny J, Yanishlieva N, Gordan M. Antioxidants in food: Practical applications. Woodhead Publishing Limited. Cambridge. 2001, 3 .

66. Pietta PG. In: Flavonoid in Health and Disease; Rice-Evans CA, Packer L ed. Marcel Dekker. New York. 1998, 110.

67. Zakaria NA, Ibrahim D, Sulaiman SF, et al. Assessment of antioxidant activity, total phenolic content and invitrontoxicity of Malaysian red seaweed, Acanthophora spicifera. J. Chem. Pharm. Res. 2011, 3(3):182-191.
68. Jain N, Goyal S, Ramawat KG. Evaluation of antioxidant properties and total phenolic content of Medicinal plants used in diet therapy during postpartum healthcare in Rajasthan. Int. J. Pharm. Pharm. Sci., 2011, 3(3): 248-253.

69. Qader SW, Abdulla MA, Chua LS, et al. Antioxidant, total phenolic content and cytotoxicity evaluation of selected malaysian plants. Molecules. 2011, 16: 3433-3443.

70. Kruawan K, Kangsadalampai K. Antioxidant activity, phenolic compound contents and antimutagenicactivity of some water extract of herbs. Thai J. Pharm. Sci. 2006, 30: 28-35. 